\title{
Institutional changes in Hungarian environmental policy between 1998 and 2018
}

\author{
Emőke KISS, István FAZEKAS \\ Department of Landscape Protection and Environmental Geography, \\ University of Debrecen, Hungary, Debrecen \\ e-mail:kiss.emoke@science.unideb.hu, fazekas.istvan@science.unideb.hu
}

Manuscript received March 10, 2019; revised April 22, 2019; Accepted April 25, 2019

\begin{abstract}
A country's economic situation, its political establishment, and the prevailing environmental conditions have a significant impact on the institutional system required for efficient environmental protection measures. During our work, we reviewed the institutional changes and legislation regarding environmental protection which have occurred over the past 20 years as well as the role of changes in the government. In summary, it can be concluded that significant changes occurred during the past two decades. The names, organizational structures, operations, and scopes of ministries have undergone regular changes over the years. In Hungary, there has been no separate ministry of the environment since 2010, and this area is regulated only on the state secretary level. In contrast, in the V4 countries and the Carpathian Basin, environmental protection is regulated on the ministry level.
\end{abstract}

Keywords: environmental ministries, environmental legislation, law

\section{Introduction}

In Hungary, several studies have been conducted over the recent years regarding environmental protection policies on the settlement and local government level $[1,2,3,4]$. We also found studies demonstrating the state of national environmental protection and its organizational system $[5,6,7,8]$; however, it is difficult to keep track of the rapid changes which have occurred with regard to the operation of the organizational system of environmental protection. During the recent years, several changes have occurred, highlighting the relevance of our study.

In Hungary, the organizational and institutional conditions of environmental protection have improved since the change of regime following the end of the 
Cold War [1]. Among the countries of the Eastern Block, Hungary was the first to establish environmental protection laws since, as a consequence of the centrally planned economy, environmental damage was more severe in comparison to countries with a similar level of economic development $[9,10]$. In Hungary, laws regarding environmental protection were established during the mid-1990s. Then, following a 3-4-year period with practically no legislative action, the rate at which new laws were passed increased disproportionately primarily because of the upcoming EU accession [6]. Following the trend of the 2000s regarding international environmental policies, climate change and waste management became central issues in Hungary, as well [1]. The establishment of a separate environmental protection ministry may help to enforce environmental interests [11]. The aim of this study is to review the organizational changes and laws passed over the last 20 years regarding environmental protection and the role of changes in government in Hungary, thereby providing a comprehensive analysis of the current situation.

\section{Materials and methods}

In order to review the hierarchy of laws, we reviewed the effective Fundamental Law and environmental acts of Hungary as well as the role played by laws, government decrees, and local government decrees regarding environmental protection. To investigate the administrative changes occurring in environmental protection, we reviewed the scope, structure, and establishment of responsible ministries, institutions, and organizations.

\section{Results and discussions}

\section{A. Hierarchy of environmental protection laws}

At the top of the hierarchy, there are the provisions of the Fundamental Law of Hungary [12]. The new, modified Law came into effect on 1 January 2012. It has five articles (Article P, Article Q, Article XX, Article XXI, and Article 38) on environment and environmental protection. This specifies the tasks and regulatory responsibilities of the government with regard to environmental protection.

Environmental laws also refer to the Fundamental Law of Hungary; its general framework is outlined in the laws of environmental protection [13]. Among other things, it stipulates the terms and principles of the regulation, its general requirements, the tasks of the state and local government as well as the specific institutions responsible for the operation of environmental protection. Several laws were established based on its provisions. There are non- 
environmental laws concerning soils, forests, mining, and nuclear energy, for instance. Furthermore, there are other, specifically environmental laws on issues such as waste as well as nature, landscape, and animal protection.

At the next level of the hierarchy, there are the government and ministry decrees. These decrees can be established only with legal permission, which is granted by the Environmental Act and other acts.

At the lowest hierarchical level, there are the local government decrees. These decrees, issued by local authorities, must be in accordance with national specifications [7]. They also play an important role at the settlement level in the fields of local environmental and nature protection, built environment, and waste management $[14,2]$.

\section{B. Changes in the organization of environmental protection administration between 1998 and 2018}

Act VII of 1987 elevated environmental protection in Hungary to a ministry level [15]. Initially, the operative tasks of environmental protection were managed in combination with water management; subsequent to this - during the 8 years following the change of regime -, they were integrated into regional development. The names, organizational structures, operations, and scopes of the ministries have undergone regular changes over the years, which is, in part, related to changes in government. In the following, we will review the changes that took place over the past two decades, taking each governmental cycle in turn.

\section{The first Orbán Government (1998-2002)}

After the change of government in 1998, the first Orbán Government was established. At that time, the name of the existing Ministry of Environment Protection and Regional Development was changed to Ministry of the Environment (ME) under Act XXXVI of 1998, while water management remained under the remit of the Ministry of Transport, Telecommunications and Water Management [16, 17]. On 8 July 1998, Dr Pál Pepó was appointed Minister for the Environment at the new ME, and he was followed by Dr Ferenc Ligetvári on 20 June 2000. As of 1 December 2000, the position was filled by Béla TuriKovács.

\section{The Medgyessy Government (2002-2004)}

After the parliamentary elections of 2002, in the governmental organization led by Péter Medgyessy, water management and environmental issues were assigned to one portfolio, under the name of the Ministry of the Environment and Water (MEW) [18], which was the legal successor of the Ministry of Environmental Protection and Water Management established by the Parliament 
in 1987 [19]. From that point on, from 27 May 2002, the leader of the ministry was Dr Mária Kóródi as Minister for Environment and Water, followed by Miklós Persányi from 19 May 2003 [8]. The structure of the MEW is shown in Figure 1. With the establishment of the National Environmental Protection and Nature Conservation and Water Management Inspectorate, a "green authority system" was formed in 2005, integrating environmental protection, nature conservation, and water management tasks.

The first and the second Gyurcsány governments (2004-2006 and 2006-2009)

The position of prime minister was filled by Ferenc Gyurcsány in 2004, who was later elected as Prime Minister in the parliamentary election of 2006. From that point on, the MEW continued to operate under the same name and with the same responsibilities. Its leader remained Miklós Persányi, followed by Dr Gábor Fodor from 7 May 2007. From 5 May 2008, the position was filled by Imre Szabó. Under Governmental Decree No 347/2006 (XII. 23.), a directorate was created to manage environmental and water management issues [20].

The Bajnai Government (2009-2010)

No changes were made to the measures taken by the former administration.

The second Orbán Government (2010-2014)

After the parliamentary elections of 2010, the position of prime minister was once again filled by Viktor Orbán. Under the Act XLII of 2010, the legal successor to the MEW was the Ministry of Rural Development (MRD) [21]. Therefore, in 2010, the issue of environmental protection was stripped of its ministry-level independence [6]. On 27 May 2010, Sándor Fazekas was appointed as the leader of the MRD as Minister for Rural Development. The scope of the MRD covers the areas of forest management, cartography, land administration, environmental protection, nature conservation, and water management [22]. The issue of environmental protection was managed only on the state secretary level. The state secretary for the environment was Dr Zoltán Illés. 


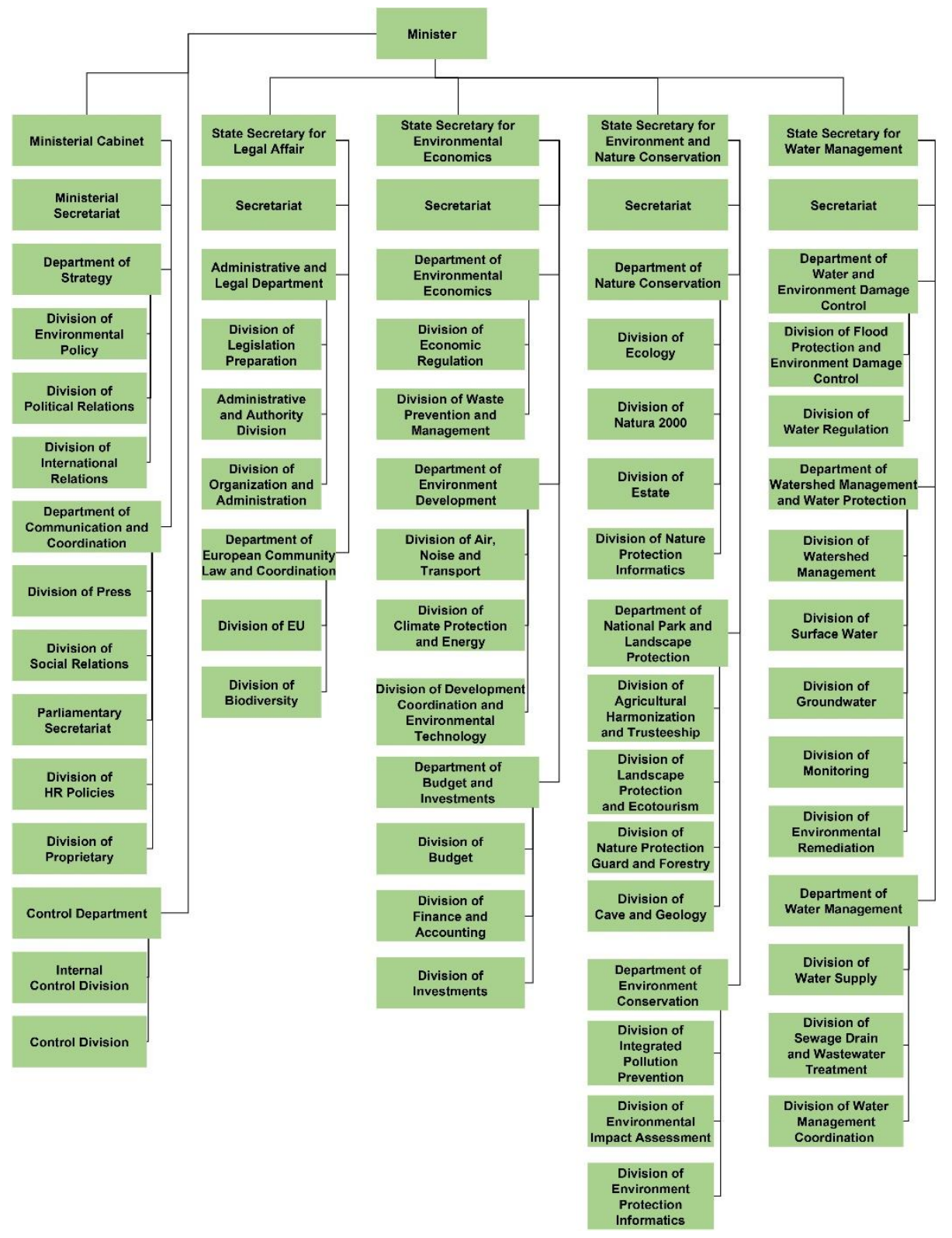

Figure 1. The structure of the Ministry of Environment and Water 
The structure of the MRD is demonstrated in Figure 2. At that time, development and climate policy, energy policy, mining, and waste management were under the responsibility of the Ministry of National Development [21, 23, 24]. At this point, the Inspectorate, which was responsible for environmental, nature, and water protection, became a central agency led by the minister [20, 25]. In 2012, the organizational structure of the administration changed. From that point on, management tasks involving water management became the responsibility of the Ministry of the Interior; however, the technical administrative tasks remained within the remit of the MRD. With the dissolution of the organization, based on Government Decree No 300/2011 (XII. 22.) as the legal successor of the VKKI, the National Environmental Protection Institute (NEPI) operated by the MRD, which managed environmental protection and water management tasks, as well as the National Water Management Directorate (NWMD) managed by the Ministry of Interior were established to coordinate the activity of the water management directorates with the 12 water management directorates formed in accordance with the prevailing hydrographic conditions [4, 6, 7, 8, 26]. Under OGY Decision No 23/2010 (V. 14.), the Hungarian Parliament's Committee on Sustainable Development was established [27]. It became responsible for the management of activities of the MRD, including environmental protection, nature conservation, and water management meteorological tasks. The committee was also responsible for issues which are technically under the scope of other ministries but are connected to environmental protection, such as protection against radioactive contamination, energy efficiency and renewable resources, chemical safety, environmental health affairs, environmental safety, and issues of transport related to environmental protection [28]. As of 1 January 2011 and 2013, the county-level and districtlevel government agencies, respectively, started their activities as the official regional state administration bodies of the government.

The centres of county-level government agencies are in the county seats, while the capital's government agency and the government agency of Pest County are located in Budapest [29].

Government agencies are responsible for the harmonization and facilitation of the regional implementation of governmental tasks in accordance with the law and with the decisions of the government. At the time they were set up, the scope of government agencies was in accordance with the environmental authority county borders. In certain cases, two or more county-level government agencies cooperated to manage specific environmental authority tasks from one centre. In accordance with the above, a total of 11 combined government agencies are responsible for the management of environmental authority tasks. 


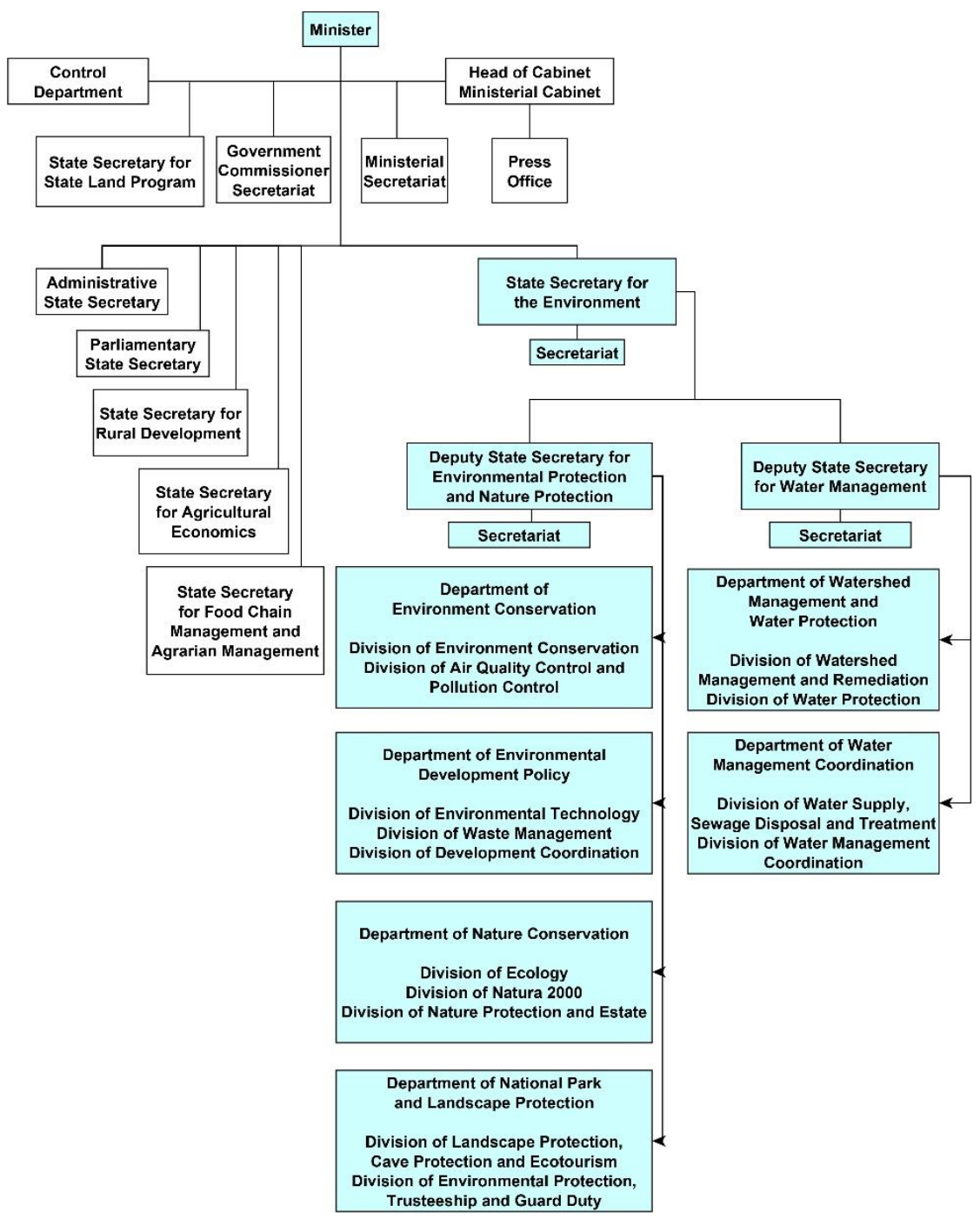

Figure 2. The structure of the Ministry of Rural Development between 2010 and 2014

The third Orbán Government (2014-2018)

After the election of 2014, Viktor Orbán remained the Prime Minister. Under Act XX of 2014, the Ministry of Rural Development (MRD) continued to operate under the name Ministry of Agriculture (MA) [30]. 
The structure of the MA is shown in Figure 3. At that time, the position of Minister for Agriculture was held by Sándor Fazekas. The scope of the MA covers the areas of forest management, land administration, environmental protection, nature conservation, and cartography [31]. For protection against catastrophes, water management, water protection, and the management of water administration bodies, the responsible organization is the Ministry of the Interior $[31,32]$.

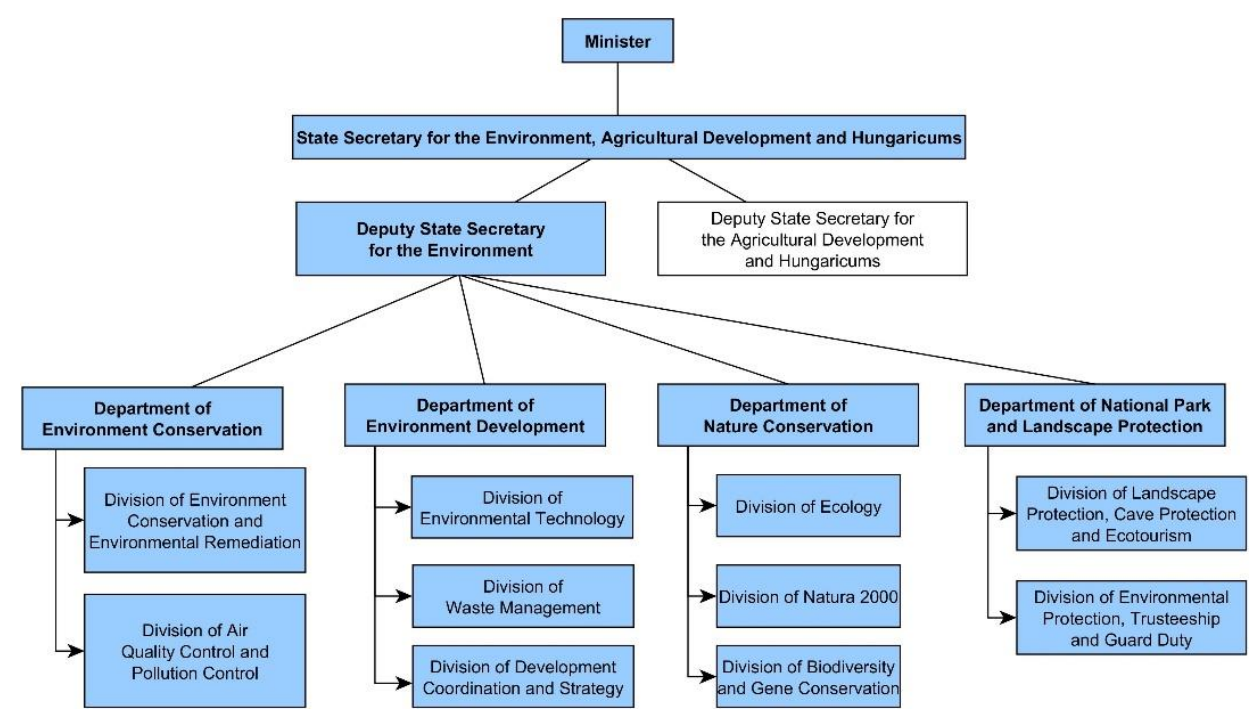

Figure 3. The structure of the Ministry of Agriculture between 2014 and 2018

Mining, waste management, and energy policy are under the scope of the Ministry of National Development [31, 33]. Energy policy covers the nonmilitary use of nuclear energy, the utilization of biofuels and other renewable fuels for transport purposes, the utilization of renewable resources for the purposes of heat and electricity production as well as creating the necessary conditions for climate policy, sustainable economic development, and energy efficiency. The issue of environmental protection was managed only on the state secretary level by Zsolt Németh, who held the position of State Secretary for the environment, agricultural development, and hungaricums (unique Hungarian products) [34].

Compared to the measures taken by the second Orbán Government, a few significant changes occurred with regard to environmental protection. Under government decrees no 223/2014 (IX. 4.) and no 71/2015 (III. 30.), water 
management and authority tasks were completely decoupled from the environmental protection and nature conservation authority and administrative tasks $[35,36]$. The government designated a Directorate of the Interior Ministry (which was responsible for the disaster management) as the national water management authority [35]. As of 1 April 2015, the environmental protection and nature conservation departments of county-level government agencies were responsible for managing the regional environmental protection and nature conservation tasks, instead of the former environmental protection and nature conservation directorates. As of 1 January 2017, the National Environmental Protection and Nature Conservation Directorate was integrated into another organization and terminated with legal succession. Its general legal successor is the Pest County Government Agency, which functions as a national-level environmental protection and nature conservation authority [37]. The district offices of county-level government agencies are responsible for regional environmental protection and nature conservation. Formerly, there were 11 combined authorities, aligned with river basin regions; however, as of 2017, they were aligned with administrative (county) borders [36]. In 2015, a new directorate, named the Environmental Sustainability Directorate, was established as part of the Office of the President of the Republic. Its main task was to monitor national and international activities related to environmental sustainability [38].

\section{The fourth Orbán Government (2018-)}

After the elections of 2018, the fourth Orbán Government was established. As per Act V of 2018, the Ministry of Agriculture (MA) (in Hungarian: Földmüvelésügyi Minisztérium) continues to operate under a modified name (in Hungarian, Agrárminisztérium) [39]. The leader of the ministry is István Nagy, holding the position of Minister for Agriculture. The scope of the Ministry of Agriculture (MA) covers the areas of forest management, land administration, environmental protection, nature conservation, and cartography [40]. The issue of environmental protection is managed only on the state secretary level by Zsolt Németh, who holds the position of State Secretary for the Environment, Agricultural Development and Hungaricums [41]. The structure of the MA is shown in Figure 4. As per Act V of 2018, the Ministry of National Development was terminated, and from that point on the fields it was responsible for (mining, waste management, energy policy, and climate policy) were managed by the newly established Ministry for Innovation and Technology. For protection against catastrophes, water management, water protection, and the management of water administration bodies, the responsible organization is still the Ministry of the Interior [40]. 


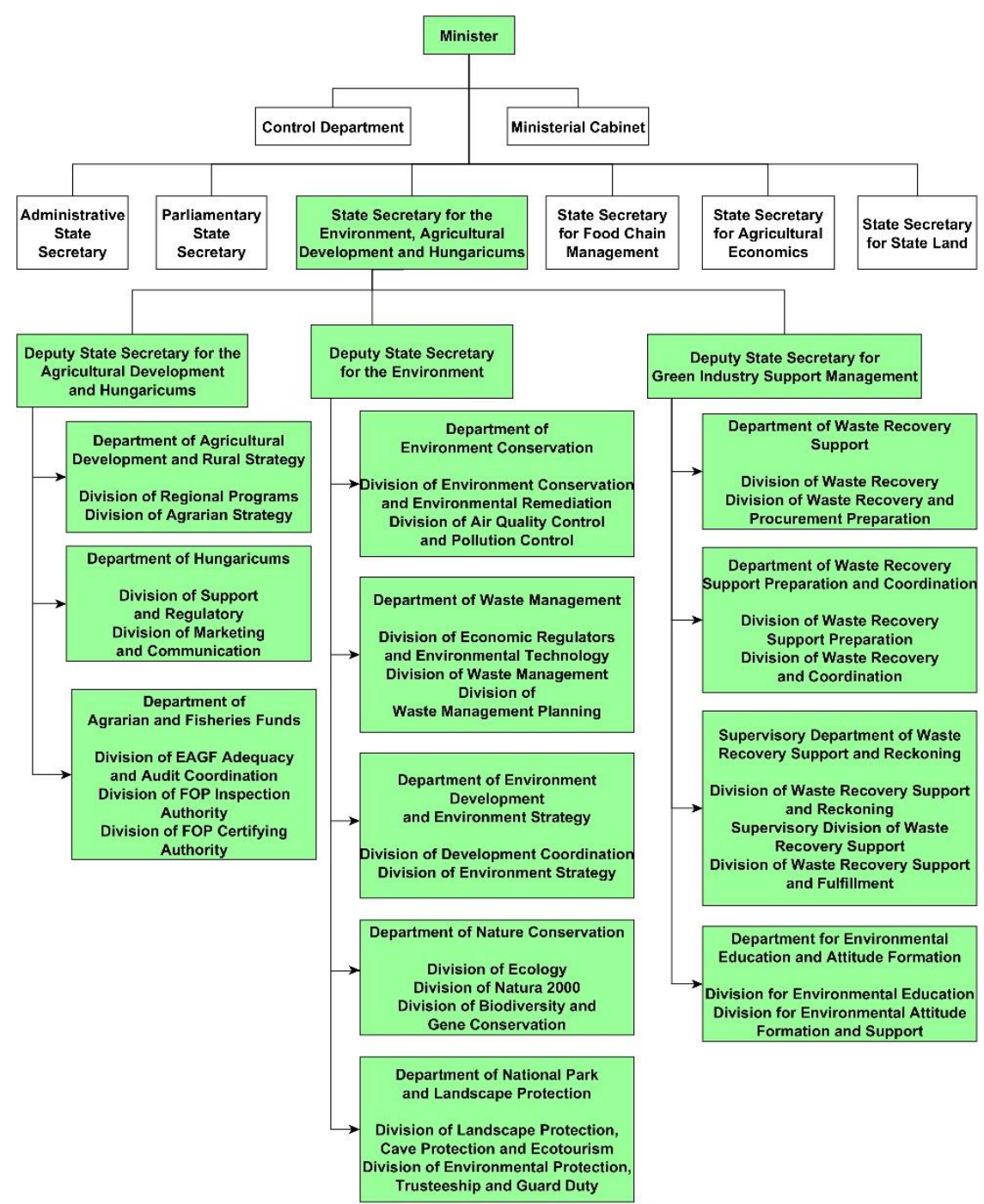

Figure 4. The structure of the Ministry of Agriculture in 2018

\section{Conclusions}

In Hungary, the last time there was a ministry responsible exclusively for environmental protection was between 1998 and 2002.

Between 2002 and 2010, there were environmental and water management ministries; since 2010, there has been no independent environmental protection ministry, and the field is represented only on the state secretary level (Figure 5). 


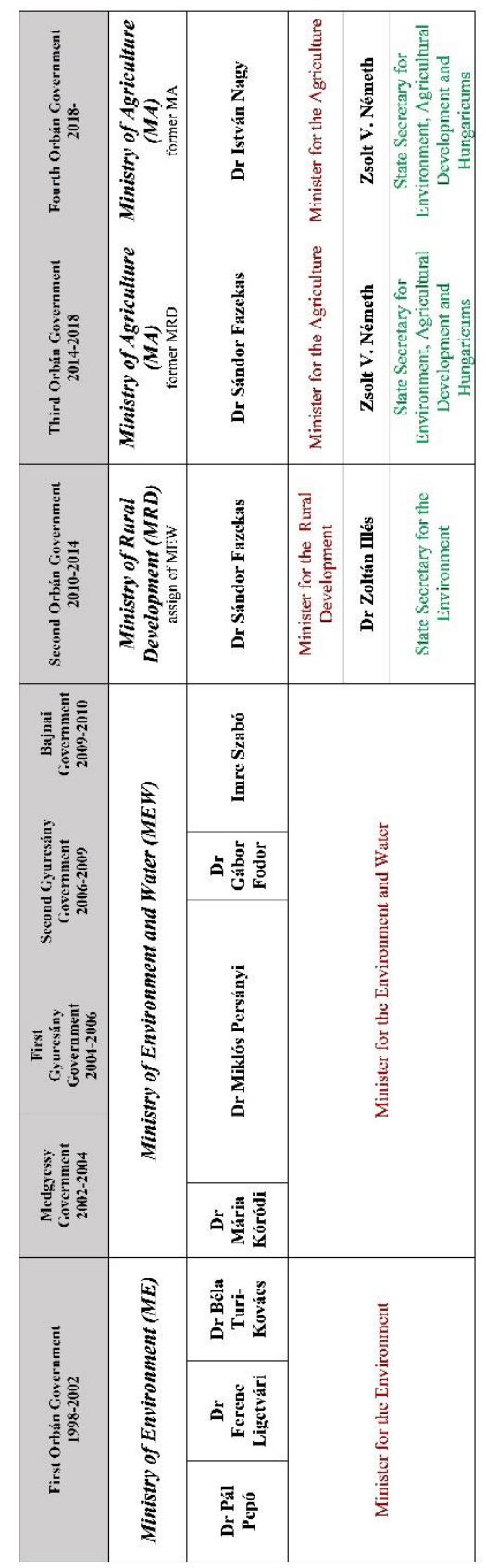

Figure 5. Institutional changes in Hungarian environmental policy 
The attempt to integrate water management and environmental protection issues into a joint administrative and authority organization was unsuccessful. In the countries of V4 and the Carpathian Basin, environmental protection is regulated on the ministry level [42-50].

\section{References}

[1] Varjú, V. (2010), A környezeti politika fejlesztéspolitikába történő integrációja - a stratégiai környezeti vizsgálat.

[2] Bányai, O. (2018), A helyi önkormányzatok környezetvédelmi szabályozása - elmélet és gyakorlat kettőssége. In: Bányai-Barta (ed.), A települési környezetvédelem elméleti és gyakorlati megközelítései. Budapest: Gondolat Kiadó. 45-68.

[3] Fodor, L. (2018), Települési környezetpolitika komplex megközelítésben. In: Bányai-Barta (ed.), A települési környezetvédelem elméleti és gyakorlati megközelitései. Budapest: Gondolat Kiadó. 69-89.

[4] Pénzes, F. (2018), Helyi szintü döntéshozatal és helyi szintű politikák kialakítása - különös tekintettel a környezeti kérdésekre. In: Bányai-Barta (ed.), A települési környezetvédelem elméleti és gyakorlati megközelitései. Budapest: Gondolat Kiadó. 138-154.

[5] Láng, I., Faragó, T., Schmuck, E., Zoltai, N. (2003), Környezetvédelem Magyarországon és az Európai Unióban [Environmental protection in Hungary and in the European Union].

[6] Bándi, Gy. (2011), Környezetjog. Budapest: Szent István Társulat.

[7] Fodor, L. (2012), Környezetvédelmi jog és igazgatás. Debrecen: Debreceni Egyetemi Kiadó.

[8] Faragó, T. (2013), A hazai környezetügy az elmúlt negyedszázadban. Budapest: Országgyülés Fenntartható Fejlődés Bizottsága.

[9] Berg, M. M. (1999), Environmental protection and the Hungarian transition. The Social Science Journal 36(2), 227-250.

[10] Miklós, L., Špinerová, A. (2009), The environmental conditions in [the] Carpathian Basin and the environmental policy of [the] European Union. Acta Universitatis Sapientiae, Agriculture and Environment 1, 83-92.

[11] Csutora, M., Kerekes, S. (2004), A környezetbarát vállalatirányítás eszközei. KJK Kerszöv.

[12] Magyarország Alaptörvénye [Fundamental Law of Hungary].

[13] 1995. évi LIII. törvény a környezet védelmének általános szabályairól [Act LIII of 1995 on the General Rules of Environmental Protection].

[14] 2011. évi CLXXXIX. törvény Magyarország helyi önkormányzatairól.

[15] 1987. évi VII. törvény a Magyar Népköztársaság minisztériumainak felsorolásáról.

[16] 1998. évi XXXVI. törvény a Magyar Köztársaság minisztériumainak felsorolásáról.

[17] 1994. évi LVI. törvény a Magyar Köztársaság minisztériumainak felsorolásáról szóló 1990. évi XXX. törvény módositásáról.

[18] 2002. évi XI. törvény a Magyar Köztársaság minisztériumainak felsorolásáról.

[19] 17/2006. (MK 94.) KvVM utasitás a Környezetvédelmi és Vizügyi Minisztérium Szervezeti és Müködési Szabályzatáról.

[20] 347/2006. (XII. 23.) Korm. rendelet a környezetvédelmi, természetvédelmi, vizügyi hatósági és igazgatási feladatokat ellátó szervek kijelöléséröl.

[21] 2010. évi XLII. törvény a Magyar Köztársaság minisztériumainak felsorolásáról.

[22] Vidékfejlesztési Minisztérium alapitó okirata 2010.

[23] Nemzeti Fejlesztési Minisztérium alapitó okirata 2010.

[24] 24/2013. (VII. 12.) NFM utasitás a Nemzeti Fejlesztési Minisztérium Szervezeti és Müködési Szabályzatáról. 
[25] Az Országos Környezetvédelmi, Természetvédelmi és Vizügyi Föfelügyelőség módositásokkal egységes szerkezetbe foglalt alapitó okirata 2010.

[26] 300/2011. (XII. 22.) Korm. rendelet a vízügyi igazgatási szervek irányitásának átalakitásával összefüggésben egyes kormányrendeletek módositásáról.

[27] 23/2010. (V . 14.) OGY határozat az Országgyülés bizottságainak létrehozásáról, tisztségviselöinek és tagjainak megválasztásáról.

[28] http://www.parlament.hu/internet/plsql/ogy_biz.keret_frissit?p_szerv=\&p_ckl=39\&p_biz= A345\&p_fomenu=10\&p_almenu $=10 \&$ p_rec $=\&$ p_egys $=\& p \_n y e l v=H U$

[29] 2010. évi CXXVI. törvény a fövárosi és megyei kormányhivatalokról, valamint a fövárosi és megyei kormányhivatalok kialakitásával és a területi integrációval összefüggö törvénymódositásokról.

[30] 2014. évi XX. törvény Magyarország minisztériumainak felsorolásáról.

[31] 152/2014. (VI. 6.) Korm. rendelet a Kormány tagjainak feladat-és hatásköréröl.

[32] Belügyminisztérium alapitó okirata 2014.

[33] Nemzeti Fejlesztési Minisztérium alapitó okirata 2014.

[34] 3/2014. (VIII. 1.) FM utasitás a Földmüvelésügyi Minisztérium Szervezeti és Müködési Szabályzatáról.

[35] 223/2014. (IX. 4.) Korm. rendelet a vízügyi igazgatási és a vízügyi, valamint a vizvédelmi hatósági feladatokat ellátó szervek kijelöléséröl.

[36] 71/2015. (III. 30.) Korm. rendelet a környezetvédelmi és természetvédelmi hatósági és igazgatási feladatokat ellátó szervek kijelöléséröl.

[37] 378/2016. (XII. 2.) Korm. rendelet egyes központi hivatalok és költségvetési szervi formában müködő minisztériumi háttérintézmények felülvizsgálatával összefüggö jogutódlásáról, valamint egyes közfeladatok átvételéröl.

[38] A Köztársasági Elnöki Hivatal I-1/05931/2014. számú szervezeti és müködési szabályzata.

[39] 2018. évi V. törvény Magyarország minisztériumainak felsorolásáról, valamint egyes kapcsolódó törvények módositásáról.

[40] 94/2018. (V. 22.) Korm. rendelet a Kormány tagjainak feladat-és hatásköréröl.

[41] Az Agrárminisztérium Szervezeti és Müködési Szabályzatáról 2018.

[42] https://www.vlada.cz/en/clenove-vlady/ministerstva/

[43] https://www.premier.gov.pl/en.html

[44] https://www.vlada.gov.sk//current-members-of-the-government/

[45] https://www.federal-chancellery.gv.at/ministries

[46] https://vlada.gov.hr/clanovi-vlade/66

[47] http://gov.ro/en/government/the-cabinet-of-ministers

[48] http://www.uzzpro.gov.rs/english/ministarstva.html

[49] http://www.vlada.si/en/about_the_government/ministries/

[50] https://www.kmu.gov.ua/en/team 